\title{
Efektivitas dan selektivitas beberapa bahan aktif herbisida untuk mengendalikan gulma pada dua varietas tanaman kacang panjang (Vigna sesquipedalis $\mathrm{L}$.)
}

\section{Effectiveness and selectivity of the herbicides active ingredients to control weeds on two varieties of long bean plants (Vigna sesquipedalis L.)}

\author{
Wahyu Eko Purnomoํㅗ Saifuddin Hasjim²* \\ ${ }^{1}$ Program Studi Agroteknologi, Fakultas Pertanian, Universitas Jember. Jl. Kalimantan No.37, Krajan Timur, \\ Sumbersari Jember 68121. \\ ${ }^{2}$ Program Studi Proteksi Tanaman, Fakultas Pertanian, Universitas Jember. Jl. Kalimantan No.37, Krajan Timur, \\ Sumbersari Jember 68121.
}

\section{INFORMASI ARTIKEL}

\author{
*Korespondensi: \\ Saifuddin Hasjim \\ saifuddinhasjim@gmail.com
}

Informasi proses: Received: 31 Mei 2020 Accepted: 12 Juli 2020 Published: 15 Juli 2020

Cara sitasi: Purnomo WE, Hasjim S. 2020. Efektivitas dan selektivitas beberapa bahan aktif herbisida untuk mengendalikan gulma pada dua varietas tanaman kacang panjang (Vigna sesquipedalis L.). Jurnal Proteksi Tanaman Tropis 1(2): 48-54

DOI: 10.19184/jptt.v1i2.17917

\begin{abstract}
Field experiments on the effectiveness and selectivity of herbicides use several active ingredients; there were Sulfentrazone, Ethyl Pirazosulfuron, and Oxifluorfen with two varieties, there were Peleton and Kanton Tavi. The purpose of the study was to discover the most effective and selective herbicide active ingredients. The study was conducted from February to May 2019. This study used a randomized block design with seven treatments, namely A (control), B (oxyfluorfen, Peleton), C (etil pirazosulfuron, Peleton), D (sulfentrazone, Peleton), E (oxyfluorfen, Kanton Tavi), F (etil pirazosulfuron, Kanton Tavi), G (sulfentrazone, Kanton Tavi). Each treatment was repeated four times. The data were analyzed used analysis of variance (ANOVA); further testing used the DMRT test with a $5 \%$ level. The results showed that the application of herbicides made from sulfentrazone, ethyl pirazosulfuron, oxyfluorfen in Peleton varieties, and Kanton Tavi could suppress weed growth in the research area. The best weed control results were shown by herbicide treatment with sulfentrazone as an active ingredient in the Kanton Tavi variant. The best long bean production results were demonstrated by herbicide treatment with sulfentrazone in Peleton varieties. The application of herbicides with active oxyfluorfen made no symptoms of phytotoxicity but decreased the yield of kanton tavi varieties and peleton varieties.
\end{abstract}

Keywords: oxifluorfen, sulfentrazone, ethyl pirazosulfuron, weeds

\section{Pendahuluan}

Kacang panjang (Vigna sesquipedalis L.) merupakan salah satu tanaman hortikultura yang tergolong sayuran kacang-kacangan. Hasil produksi kacang panjang di Indonesia pada tahun 2011 sampai dengan tahun 2014 cenderung mengalami penurunan, pada tahun 2011 produksinya mencapai 458.307 ton, tahun 2012 mencapai 455.562 ton, tahun 2013 mencapai 450.859 ton, dan pada tahun 2014 sebesar 450.709 ton (Direktorat Jenderal Hortikultura Kementerian Pertanian 2015). Usaha peningkatan produksi tanaman kacang panjang dihadapkan pada berbagai kendala, diantaranya alih fungsi lahan 
pertanian menjadi non-pertanian, degradasi kesuburan lahan, perubahan iklim, dan adanya serangan organisme pengganggu tanam, salah satunya yaitu gulma.

Gulma yang tumbuh di sekitar tanaman kacang panjang dapat menghambat pertumbuhan dan produksi kacang panjang. Tanaman kacang panjang yang dibudidayakan pada lahan yang tidak dilakukan pengendalian gulma dapat menyebabkan penurunan produksi sebesar 0,103 ton/ha (Sarido 2018). Keberadaan gulma selain menjadi tanaman pesaing juga sebagai sarang atau inang hama dan penyakit tanaman yang menimbulkan penurunan produksi (Christia et al. 2016). Selain penurunan produksi, adanya gulma di pertanaman kacang panjang juga menyebabkan biaya pengendalian yang besar sehingga menurunkan pendapatan petani. Hal ini membuktikan bahwa masalah gulma menjadi sangat serius pada pertanaman kacang panjang.

Pengendalian gulma secara manual saat ini menghadapi masalah kurangnya tenaga kerja di bidang pertanian, sehingga biaya penyiangan manual semakin mahal, oleh karena itu salah satu alternatifnya adalah pengendalian gulma dengan menggunakan herbisida. Pemilihan bahan aktif yang terkandung dalam herbisida menjadi salah satu faktor yang menentukan keberhasilan pengendalian gulma. Bahan aktif herbisida yang dapat digunakan untuk pengendalian gulma pada pertanaman kacang panjang diantaranya adalah herbisida berbahan aktif sulfentrazon, etil pirazosulfuron, dan oksifluorfen. Herbisida ini diharapkan dapat mengendalikan gulma umum pada pertanaman kacang panjang. Pengujian lapang mengenai efektivitas dan selektivitas bahan aktif herbisida bertujuan untuk mengetahui tingkat efektivitas dan selektivitas dari herbisida berbahan aktif sulfentrazon, etil pirazosulfuron, dan oksifluorfen untuk mengendalikan gulma pada tanaman kacang panjang.

\section{Metode penelitian}

Penelitian dilakukan di lahan Kelurahan Wirolegi, Kecamatan Sumbersari, Kabupaten Jember mulai Februari sampai Mei 2019. Bahan yang digunakan dalam penelitian ini adalah herbisida dengan bahan aktif sulfentrazon, etil pirazosulfuron, dan oksifluorfen. Bahan tanam yang digunakan adalah benih kacang panjang varietas peleton dan kanton tavi. Sarana produksi yang digunakan antara lain pupuk ZA, SP-36, dan KCl. Peralatan yang digunakan adalah sprayer otomatis, timbangan analitik, dan oven.

Percobaan dilakukan dengan menggunakan Rancangan Acak Kelompok dengan 7 perlakuan dan 4 ulangan. Perlakuan yang diberikan yaitu tanpa aplikasi herbisida (A), herbisida berbahan aktif oksifluorfen pada varietas peleton (B), herbisida berbahan aktif etil pirazosulfuron pada varietas peleton (C), herbisida berbahan aktif sulfentrazon pada varietas peleton (D), herbisida berbahan aktif oksifluorfen pada varietas kanton tavi (E), herbisida berbahan aktif etil pirazosulfuron pada varietas kanton tavi $(\mathrm{F})$, dan herbisida berbahan aktif sulfentrazon pada varietas kanton tavi (G). Satuan percobaan berupa petak dengan ukuran 3 meter $\times 2$ meter.

Persiapan lahan dilakukan dengan pembajakan dan pembuatan petak percobaan dengan ukuran $3 \mathrm{~m} \times 2 \mathrm{~m}$ sebanyak 28 petak percobaan. Benih kacang panjang ditanam pada petak percobaan dengan membuat lubang tanam, jarak tanam yang digunakan $50 \mathrm{~cm} \times 50$ $\mathrm{cm}$.

Dosis herbisida yang digunakan sesuai dengan anjuran dosis formulasi pada merk dagang. Aplikasi herbisida dilakuakan 1 hari setelah tanam menggunakan alat semprot otomatis dengan volume semprot 362,71 L/ha. Pemupukan pada saat sebelum tanam menggunakan SP-36 $100 \mathrm{~kg} / \mathrm{ha}$ dan $\mathrm{KCl} 50$ $\mathrm{kg} / \mathrm{ha}$. Pemupukan ZA diberikan secara bertahap setengah bagian diberikan pada umur satu minggu dan setengah bagian lagi diberikan pada umur empat minggu setelah tanam. Pemasangan lanjaran dilakukan 10 sampai 15 hari setelah tanam.

Pemanenan dilakukan pada saat tanaman umur 48 sampai 55 hari setelah tanam. Variabel pengamatan gulma yitu inventarisasi gulma yang dilakukan sebelum pengolahan lahan dengan menggunakan 5 unit sampel berukuran $1 \mathrm{~m} \times 1 \mathrm{~m}$ yang ditempatkan secara diagonal pada lahan percobaan. Gulma yeng terdapat pada unit sampel dicabut dan diidentifikasi berdasakan spesies, famili, dan golongan kemudian dilakukan pengambilan gambar. Pengamatan biomassa gulma dan efektivitas herbisida dilakukan pada saat 14, 28, 42, dan 56 hari setelah tanam. Pengamatan biomasa gulma dilakukan dengan pengambilan unit sampel berukuran $30 \mathrm{~cm} \times 30 \mathrm{~cm}$ yang ditentukan secara acak pada petak percobaan. Gulma dipotong diatas permukaan tanah dan dipisahkan berdasarkan spesiesnya kemudian dimasukan kedalam amplop kertas dan dioven pada suhu $80^{\circ} \mathrm{C}$ selama 24 jam kemudian ditimbang berat keringnya. Pengamatan efektivitas herbisida dilakukan dengan skoring mengikuti Tabel 1.

Tabel 1. Skoring pengamatan efektivitas herbisida

\begin{tabular}{llc}
\hline Skor & Efikasi (Matinya Gulma) & (\%) Converage \\
\hline 9 & Seluruh gulma mati & 100 \\
8 & Daya bunuh sangat baik & $99,9-98$ \\
7 & Daya bunuh baik sekali & $97,9-95$ \\
6 & Baik & $94,9-90$ \\
5 & Sedang & $89,9-82$ \\
4 & Cukup & $81,9-70$ \\
3 & Jelek & $69,9-65$ \\
2 & Sangat jelek & $64,9-30$ \\
1 & Tidak berpengaruh & $29,9-0$ \\
\hline
\end{tabular}

Variabel pertumbuhan tanaman yang diamati yaitu fitotoksisitas, tinggi tanaman, jumlah daun, dan laju pertumbuhan tanaman yang dilakukan pada saat 14 , 28, 42, dan 56 hari setelah tanam. Fitotoksisitas 
Tabel 2. Hasil inventarisasi gulma

\begin{tabular}{lll}
\hline Jenis Spesies Gulma & Famili & Golongan \\
\hline Amaranthus viridis L & Amaranthaceae & Daun lebar \\
Alternanthera sessilis L. & Amaranthaceae & Daun Lebar \\
Ageratum conyzoides L. & Asteraceae & Daun lebar \\
Cyanthillium cinereum L. & Asteraceae & Daun Lebar \\
Tridax procumbens L. & Asteraceae & Daun Lebar \\
Eclipta prostrata L. & Asteraceae & Daun Lebar \\
Commelina benghalensis L. & Commelinaceae & Daun Lebar \\
Commelina diffusa L. & Commelinaceae & Daun Lebar \\
Acalypha indica L. & Euphorbiaceae & Daun Lebar \\
Phyllanthus urinaria L. & Euphorbiaceae & Daun Lebar \\
Mimosa pudica L. & Fabaceae & Daun Lebar \\
Portulaca oleracea L. & Portulacaceae & Daun Lebar \\
Hedyotis corymbosa L. & Rubiaceae & Daun Lebar \\
Cynodon dactylon L. & Poaceae & Rumput \\
Agrostis capillaris L. & Poaceae & Rumput \\
Digitaria ciliaris Retz.) Koel. & Poaceae & Rumput \\
Bachiaria reptans L. $($ Garden. $\&$ Hubs.) & Graminae & Rumput \\
Cyperus rotundus L. & Cyperaceae & Teki \\
\hline
\end{tabular}

diamati secara visual terhadap gejala-gejala perubahan fisiologis tanaman. Pengamatan dilakukan dengan cara skoring yaitu:

$0=$ tidak ada keracunan, $0-5 \%$ bentuk daun atau warna daun dan atau pertumbuhan tanaman tidak normal;

$1=$ keracunan ringan, $>5-20 \%$ bentuk daun atau warna daun dan atau pertumbuhan tanaman tidak normal;

$2=$ keracunan sedang, $>20-50 \%$ bentuk daun atau warna daun dan atau pertumbuhan tanaman tidak normal;

$3=$ keracunan berat, $>50-70 \%$ bentuk daun atau warna daun dan atau pertumbuhan tanaman tidak normal;

$4=$ keracunan sangat berat, $>70 \%$ bentuk daun atau warna daun dan atau pertumbuhan tanaman tidak normal sampai tanaman mati (Guntoro et al. 2013).

Variabel produksi tanaman kacang panjang yang diamati yaitu jumlah polong, panjang polong dan berat segar. Pengamatan dilakukan mulai dengan pemanenan pertama sekitar umur 48 hari sampai dengan panen ketujuh dengan interval pemanenan 3 hari sekali.

Analisis data dilakukan menggunakan sidik ragam. Apabila perlakuan menunjukan pengaruh nyata dilanjutkan dengan uji Duncan Multiple Range Test (DMRT) dengan taraf 5\%.

\section{Hasil dan Pembahasan}

\section{Inventarisasi Gulma}

Hasil pengamatan menunjukkan bahwa terdapat 18 spesies gulma dari 10 famili yang terbagi kedalam 3 golongan berdasarkan respon terhadap herbisida (Tabel 2).

\section{Biomassa Gulma Berdaun Lebar}

Hasil penelitian menunjukkan bahwa perlakuan bahan aktif herbisida yang diaplikasikan dapat mengendalikan gulma berdaun lebar, ditunjukkan dengan bobot kering biomassa gulma berdaun lebar yang nyata lebih rendah dibandingkan dengan perlakuan kontrol pada pengamatan 14 HST sampai 56 HST (Tabel 3).

\section{Biomassa Gulma Teki}

Hasil penelitian menunjukkan bahwa perlakuan bahan aktif herbisida yang diaplikasikan dapat mengendalikan gulma berdaun lebar, ditunjukkan dengan bobot kering biomassa gulma teki yang nyata lebih rendah dibandingkan dengan perlakuan kontrol pada pengamatan 14 HST sampai 56 HST (Tabel 4).

\section{Biomassa Gulma Rumput}

Hasil penelitian menunjukkan bahwa perlakuan bahan aktif herbisida yang diaplikasikan dapat menekan pertumbuhan gulma rumput, ditunjukkan dengan bobot kering biomassa gulma rumput lebih rendah dibandingkan dengan perlakuan kontrol pada kacang panjang, ditunjukkan dengan hasil skoring fitotoksisitas 0 pada semua perlakuan mulai pengamatan 14 HST sampai 56 HST (Tabel 5).

\section{Efektifvitas Herbisida}

Hasil penelitian menunjukkan bahwa perlakuan bahan aktif herbisida yang diaplikasikan dapat mengendalikan gulma total, ditunjukkan dengan skoring efektivitas herbisida yang nyata lebih tinggi dibandingkan dengan perlakuan kontrol pada pengamatan 14 HST sampai dengan 56 HST (Tabel 6). 
Tabel 3. Pengaruh aplikasi herbisida etil pirazosulfuron, oksifluorfen, dan sulfentrazon terhadap biomassa gulma berdaun lebar

\begin{tabular}{lllll}
\hline \multirow{2}{*}{ Perlakuan } & \multicolumn{4}{c}{ Berat Kering Gulma Berdaun Lebar (gram) } \\
\cline { 2 - 5 } & $14 \mathrm{Hst}$ & $28 \mathrm{Hst}$ & $42 \mathrm{Hst}$ & $56 \mathrm{Hst}$ \\
\hline A (Kontrol) & $1,92 \mathrm{~b}$ & $4,79 \mathrm{~d}$ & $5,98 \mathrm{c}$ & $6,03 \mathrm{c}$ \\
B (Oksifluorfen, peleton) & $0,46 \mathrm{a}$ & $0,77 \mathrm{ab}$ & $2,41 \mathrm{ab}$ & $3,18 \mathrm{a}$ \\
C (Etil pirazosulfuron, peleton) & $0,60 \mathrm{a}$ & $2,44 \mathrm{c}$ & $3,17 \mathrm{ab}$ & $4,12 \mathrm{~b}$ \\
D (Sulfentrazon, peleton) & $0,42 \mathrm{a}$ & $0,74 \mathrm{ab}$ & $1,62 \mathrm{a}$ & $2,61 \mathrm{a}$ \\
E (Oksifluorfen, kanton tavi) & $0,58 \mathrm{a}$ & $0,92 \mathrm{ab}$ & $2,28 \mathrm{ab}$ & $3,14 \mathrm{a}$ \\
F (Etil pirazosulfuron, kanton tavi) & $0,62 \mathrm{a}$ & $1,93 \mathrm{bc}$ & $4,05 \mathrm{bc}$ & $4,70 \mathrm{~b}$ \\
G (Sulfentrazon, kanton tavi) & $0,41 \mathrm{a}$ & $0,69 \mathrm{a}$ & $1,60 \mathrm{a}$ & $2,61 \mathrm{a}$ \\
\hline
\end{tabular}

Keterangan: Angka-angka pada kolom yang sama diikuti oleh huruf yang sama menunjukkan berbeda tidak nyata pada uji DMRT taraf $5 \%$

Tabel 4. Pengaruh aplikasi herbisida etil pirazosulfuron, oksifluorfen, dan sulfentrazon terhadap biomassa gulma teki.

\begin{tabular}{lllll}
\hline \multirow{2}{*}{ Perlakuan } & \multicolumn{4}{c}{ Berat Kering Gulma Teki (gram) } \\
\cline { 2 - 5 } & $14 \mathrm{Hst}$ & $28 \mathrm{Hst}$ & $42 \mathrm{Hst}$ & $56 \mathrm{Hst}$ \\
\hline A (Kontrol) & $1,48 \mathrm{~b}$ & $3,25 \mathrm{~d}$ & $5,06 \mathrm{~b}$ & $4,85 \mathrm{c}$ \\
B (Oksifluorfen, peleton) & $0,74 \mathrm{a}$ & $1,61 \mathrm{bc}$ & $3,21 \mathrm{ab}$ & $3,27 \mathrm{a}$ \\
C (Etil pirazosulfuron, peleton) & $0,80 \mathrm{a}$ & $1,94 \mathrm{c}$ & $3,85 \mathrm{~b}$ & $4,68 \mathrm{bc}$ \\
D (Sulfentrazon, peleton) & $0,69 \mathrm{a}$ & $1,05 \mathrm{ab}$ & $1,62 \mathrm{a}$ & $2,71 \mathrm{a}$ \\
E (Oksifluorfen, kanton tavi) & $0,78 \mathrm{a}$ & $1,76 \mathrm{c}$ & $3,22 \mathrm{ab}$ & $3,56 \mathrm{ab}$ \\
F (Etil pirazosulfuron, kanton tavi) & $0,83 \mathrm{a}$ & $1,91 \mathrm{c}$ & $3,87 \mathrm{~b}$ & $4,81 \mathrm{c}$ \\
G (Sulfentrazon, kanton tavi) & $0,65 \mathrm{a}$ & $0,68 \mathrm{a}$ & $1,55 \mathrm{a}$ & $2,56 \mathrm{a}$ \\
\hline
\end{tabular}

Keterangan: Angka-angka pada kolom yang sama diikuti oleh huruf yang sama menunjukkan berbeda tidak nyata pada uji DMRT taraf $5 \%$.

Tabel 5. Pengaruh aplikasi herbisida etil pirazosulfuron, oksifluorfen, dan sulfentrazon terhadap biomassa gulma rumput.

\begin{tabular}{lllll}
\hline \multirow{2}{*}{ Perlakuan } & \multicolumn{4}{c}{ Berat Kering Gulma Rumput (gram) } \\
\cline { 2 - 5 } & $14 \mathrm{hst}$ & $28 \mathrm{hst}$ & $42 \mathrm{hst}$ & $56 \mathrm{hst}$ \\
\hline A (Kontrol) & 0,96 & 2,35 & 4,10 & 4,55 \\
B (Oksifluorfen, peleton) & 0,63 & 1,45 & 3,42 & 3,70 \\
C (Etil pirazosulfuron, peleton) & 0,74 & 1,52 & 3,67 & 4,29 \\
D (Sulfentrazon, peleton) & 0,56 & 1,36 & 2,93 & 3,56 \\
E (Oksifluorfen, kanton tavi) & 0,65 & 1,51 & 3,36 & 3,91 \\
F (Etil pirazosulfuron, kanton tavi) & 0,83 & 1,71 & 3,93 & 4,32 \\
G (Sulfentrazon, kanton tavi) & 0,52 & 1,15 & 2,89 & 3,53 \\
\hline
\end{tabular}

Tabel 6. Skor efektivitas hebisida berbahan aktif etil pirazosulfuron, oksifluorfen, dan sulfentrazon dalam mengendalikan gulma pada tanaman kacang panjang.

\begin{tabular}{llccc}
\hline \multirow{2}{*}{ Perlakuan } & \multicolumn{4}{c}{ Skoring Efektivitas Pengendalian Gulma } \\
\cline { 2 - 5 } & $14 \mathrm{Hst}$ & $28 \mathrm{Hst}$ & $42 \mathrm{Hst}$ & $56 \mathrm{Hst}$ \\
\hline A (Kontrol) & $1,00 \mathrm{~b}$ & $1,00 \mathrm{c}$ & $1,00 \mathrm{~b}$ & $1,00 \mathrm{~d}$ \\
B (Oksifluorfen, peleton) & $7,75 \mathrm{a}$ & $6,75 \mathrm{a}$ & $6,25 \mathrm{ab}$ & $4,25 \mathrm{ab}$ \\
C (Etil pirazosulfuron, peleton) & $7,50 \mathrm{a}$ & $4,50 \mathrm{~b}$ & $3,50 \mathrm{~b}$ & $2,25 \mathrm{c}$ \\
D (Sulfentrazon, peleton) & $8,00 \mathrm{a}$ & $7,25 \mathrm{a}$ & $6,75 \mathrm{a}$ & $4,75 \mathrm{a}$ \\
E (Oksifluorfen, kanton tavi) & $7,75 \mathrm{a}$ & $6,75 \mathrm{a}$ & $6,25 \mathrm{ab}$ & $4,00 \mathrm{~b}$ \\
F (Etil pirazosulfuron, kanton tavi) & $7,50 \mathrm{a}$ & $4,25 \mathrm{~b}$ & $3,50 \mathrm{~b}$ & $2,00 \mathrm{c}$ \\
G (Sulfentrazon, kanton tavi) & $8,00 \mathrm{a}$ & $7,50 \mathrm{a}$ & $6,75 \mathrm{a}$ & $4,75 \mathrm{a}$ \\
\hline
\end{tabular}

Keterangan: Angka-angka pada kolom yang sama diikuti oleh huruf yang sama menunjukkan berbeda tidak nyata pada uji DMRT taraf $5 \%$.

\section{Fitotoksisitas}

Hasil penelitian menunjukkan bahwa perlakuan bahan aktif herbisida yang diaplikasikan tidak menunjukkan adanya gejala perubahan fisiologis sebagai dampak keracunan herbisida pada tanaman kacang panjang, ditunjukkan dengan hasil skoring fitotoksisitas 0 pada semua perlakuan mulai pengamatan 14 HST sampai 56 HST (Tabel 7). 
Tabel 7. Skoring pengaruh herbisida etil pirazosulfuron, oksifluorfen, dan sulfentrazon terhadap keracunan tanaman kacang panjang.

\begin{tabular}{|c|c|c|c|c|}
\hline \multirow{2}{*}{ Perlakuan } & \multicolumn{2}{|c|}{ Skoring Tingkat Keracunan } & \multirow[b]{2}{*}{$42 \mathrm{Hst}$} & \multirow[b]{2}{*}{$56 \mathrm{Hst}$} \\
\hline & $14 \mathrm{Hst}$ & $28 \mathrm{Hst}$ & & \\
\hline A (Kontrol) & 0 & 0 & 0 & 0 \\
\hline B (Oksifluorfen, peleton) & 0 & 0 & 0 & 0 \\
\hline C (Etil pirazosulfuron, peleton) & 0 & 0 & 0 & 0 \\
\hline D (Sulfentrazon, peleton) & 0 & 0 & 0 & 0 \\
\hline E (Oksifluorfen, kanton tavi) & 0 & 0 & 0 & 0 \\
\hline F (Etil pirazosulfuron, kanton tavi) & 0 & 0 & 0 & 0 \\
\hline G (Sulfentrazon, kanton tavi) & 0 & 0 & 0 & 0 \\
\hline
\end{tabular}

Tabel 8. Pengaruh herbisida berbahan aktif etil pirazosulfuron, oksifluorfen, dan sulfentrazon terhadap tinggi tanaman.

\begin{tabular}{lllll}
\hline \multirow{2}{*}{ Perlakuan } & \multicolumn{5}{l}{ Tinggi Tanaman Kacang Panjang (cm) } \\
\cline { 2 - 5 } & $14 \mathrm{Hst}$ & $28 \mathrm{Hst}$ & $42 \mathrm{Hst}$ & $56 \mathrm{Hst}$ \\
\hline A (Kontrol) & $11,85 \mathrm{c}$ & $39,00 \mathrm{c}$ & $143,25 \mathrm{~b}$ & $175,38 \mathrm{~b}$ \\
B (Oksifluorfen, peleton) & $15,78 \mathrm{ab}$ & $98,26 \mathrm{a}$ & $196,50 \mathrm{a}$ & $235,06 \mathrm{a}$ \\
C (Etil pirazosulfuron, peleton) & $13,66 \mathrm{bc}$ & $62,16 \mathrm{bc}$ & $165,34 \mathrm{~b}$ & $198,50 \mathrm{~b}$ \\
D (Sulfentrazon, peleton) & $17,65 \mathrm{a}$ & $102,53 \mathrm{a}$ & $206,81 \mathrm{a}$ & $240,94 \mathrm{a}$ \\
E (Oksifluorfen, kanton tavi) & $14,73 \mathrm{abc}$ & $84,38 \mathrm{ab}$ & $195,81 \mathrm{a}$ & $231,25 \mathrm{a}$ \\
F (Etil pirazosulfuron, kanton tavi) & $13,34 \mathrm{bc}$ & $63,75 \mathrm{bc}$ & $151,31 \mathrm{~b}$ & $197,25 \mathrm{~b}$ \\
G (Sulfentrazon, kanton tavi) & $18,46 \mathrm{a}$ & $104,25 \mathrm{a}$ & $219,81 \mathrm{a}$ & $260,94 \mathrm{a}$ \\
\hline
\end{tabular}

Keterangan: Angka-angka pada kolom yang sama diikuti oleh huruf yang sama menunjukkan berbeda tidak nyata pada uji DMRT taraf $5 \%$.

Tabel 9. Pengaruh herbisida berbahan aktif etil pirazosulfuron, oksifluorfen, dan sulfentrazon terhadap jumlah daun tanaman kacang panjang.

\begin{tabular}{lllll}
\hline \multirow{2}{*}{ Perlakuan } & \multicolumn{4}{l}{ Jumlah Daun Tanaman Kacang Panjang (cm) } \\
\cline { 2 - 5 } & $14 \mathrm{Hst}$ & $28 \mathrm{Hst}$ & $42 \mathrm{Hst}$ & $56 \mathrm{Hst}$ \\
\hline A (Kontrol) & $5,81 \mathrm{~b}$ & $12,38 \mathrm{c}$ & $36,31 \mathrm{c}$ & $52,19 \mathrm{c}$ \\
B (Oksifluorfen, peleton) & $7,44 \mathrm{a}$ & $25,06 \mathrm{a}$ & $51,81 \mathrm{a}$ & $68,13 \mathrm{a}$ \\
C (Etil pirazosulfuron, peleton) & $6,44 \mathrm{ab}$ & $23,38 \mathrm{a}$ & $44,31 \mathrm{abc}$ & $61,69 \mathrm{abc}$ \\
D (Sulfentrazon, peleton) & $7,50 \mathrm{a}$ & $26,56 \mathrm{a}$ & $52,00 \mathrm{a}$ & $68,25 \mathrm{a}$ \\
E (Oksifluorfen, kanton tavi) & $7,19 \mathrm{a}$ & $23,69 \mathrm{a}$ & $47,56 \mathrm{ab}$ & $64,19 \mathrm{ab}$ \\
F (Etil pirazosulfuron, kanton tavi) & $6,44 \mathrm{ab}$ & $17,31 \mathrm{~b}$ & $38,44 \mathrm{bc}$ & $56,50 \mathrm{bc}$ \\
G (Sulfentrazon, kanton tavi) & $7,50 \mathrm{a}$ & $28,31 \mathrm{a}$ & $55,88 \mathrm{a}$ & $73,81 \mathrm{a}$ \\
\hline
\end{tabular}

Keterangan: Angka-angka pada kolom yang sama diikuti oleh huruf yang sama menunjukkan berbeda tidak nyata pada uji DMRT taraf $5 \%$.

Tabel 10. Pengaruh herbisida berbahan aktif etil pirazosulfuron, oksifluorfen, dan sulfentrazon terhadap laju pertumbuhan tanaman kacang panjang.

\begin{tabular}{llll}
\hline Perlakuan & \multicolumn{2}{l}{ Laju Pertumbuhan Tanaman Kacang Panjang (gram/hari) Perlakuan } \\
\cline { 2 - 3 } & $14 \mathrm{Hst}$ & $28 \mathrm{Hst}$ & $42 \mathrm{Hst}$ \\
\hline A (Kontrol) & $0,08 \mathrm{~b}$ & $0,28 \mathrm{c}$ & $0,31 \mathrm{e}$ \\
B (Oksifluorfen, peleton) & $0,17 \mathrm{a}$ & $0,47 \mathrm{abc}$ & $0,49 \mathrm{bc}$ \\
C (Etil pirazosulfuron, peleton) & $0,14 \mathrm{a}$ & $0,83 \mathrm{bc}$ \\
D (Sulfentrazon, peleton) & $0,17 \mathrm{a}$ & $0,29 \mathrm{c}$ & $0,34 \mathrm{de}$ \\
E (Oksifluorfen, kanton tavi) & $0,15 \mathrm{a}$ & $0,55 \mathrm{ab}$ & $0,56 \mathrm{~b}$ \\
F (Etil pirazosulfuron, kanton tavi) & $0,14 \mathrm{a}$ & $0,39 \mathrm{bc}$ & $0,42 \mathrm{~cd}$ \\
G (Sulfentrazon, kanton tavi) & $0,17 \mathrm{a}$ & $0,34 \mathrm{c}$ & $0,34 \mathrm{de}$ \\
\hline
\end{tabular}

Keterangan: Angka-angka pada kolom yang sama diikuti oleh huruf yang sama menunjukkan berbeda tidak nyata pada uji DMRT taraf $5 \%$.

\section{Tinggi Tanaman}

Hasil pengamatan tinggi tanaman pada aplikasi bahan aktif herbisida menunjukkan pengaruh nyata pada pengamatan 14 HST sampai dengan 56 HST jika dibandingkan dengan perlakuan kontrol. Perlakuan herbisida berbahan aktif etil pirazosulfuron pada varietas peleton dan kanton tavi menunjukkan 
perbedaan tinggi tanaman yang tidak nyata dengan perlakuan kontrol mulai pengamatan 14 HST sampai 56 HST (Tabel 8).

\section{Jumlah Daun}

Hasil pengamatan jumlah daun tanaman kacang panjang pada aplikasi bahan aktif herbisida menunjukkan pengaruh nyata pada pengamatan 14 HST sampai dengan 56 HST jika dibandingkan dengan perlakuan kontrol. Perlakuan herbisida berbahan aktif etil pirazosulfuron pada varietas peleton dan kanton tavi menunjukkan perbedaan jumlah daun yang tidak nyata dengan perlakuan kontrol pada pengamatan 14 HST, 42HST, dan 56 HST (Tabel 9).

\section{Laju Pertumbuhan Tanaman}

Aplikasi herbisida berbahan aktif sulfentrazon pada varietas peleton dan kanton tavi dapat meningkatkan laju pertumbuhan tanaman sampai dengan pengamatan 56 HST. Aplikasi herbisida berbahan aktif oksifluorfen pada varietas peleton dan kanton tavi menuunjukkan laju pertumbuhan yang berbeda tidak nyata dengan perlakuan kontrol pada pengamatan 28HST. Perlakuan herbisida berbahan aktif etil pirazosulfuron pada varietas peleton dan kanton tavi menunjukkan perbedaan laju pertumbuhan yang tidak nyata dengan perlakuan kontrol pada pengamatan 28 HST, 42HST, dan 56 HST (Tabel 10).

\section{Produksi Tanaman Kacang Panjang}

Aplikasi herbisida berbahan aktif sulfentrazon pada varietas peleton dan kanton tavi menunjukkan jumlah polong dan berat segar yang nyata lebih tinggi dibandingkan dengan perlakuan kontrol. Perlakuan aplikasi herbisida yang diberikan menunjukkan pengaruh tidak nyata pada variabel produksi panjang polong (Tabel 11).

\section{Pembahasan}

Aplikasi herbisida berbahan aktif oksifluorfen, etil pirazosulfuron dan sulfentrazon menunjukkan pengaruh penekanan pertumbuhan gulma pada petak percobaan. Hasil pengamatan menunjukkan bahwa aplikasi herbisida oksifluorfen dan sulfentrazon pada varietas peleteon dan kanton tavi mampu menghambat pertumbuhan gulma berdaun lebar dan teki, ditunjukkan dengan hasil yang berbeda nyata pada berat kering gulma berdaun lebar (Tabel 3) dan gulma teki (Tabel 4) jika dibandingkan dengan perlakuan kontrol sampai dengan pengamatan 56 HST. Pada penelitian ini aplikasi herbisida berbahan aktif oksifluorfen, etil pirazosulfuron dan sulfentrazon menunjukkan hasil yang kurang efektif dalam mengendalikan gulma rumput, hal ini ditunjukkan pada pengamatan berat kering gulma rumput memberikan hasil yang berbeda tidak nyata dengan perlakuan kontrol, hal ini disebabkan populasi glma rumput pada lahan penelitian cukup rendah sehingga pengaruh aplikasi herbisida yang diberikan tidak terlihat nyata. Simanjuntak et al. (2016), menjelaskan bahwa translokasi bahan aktif etil pirazosulfuron pada gulma brdaun sempit termasuk lambat sehingga membuat gulma jenis ini menjadi lebih tahan terhadap bahan aktif tersebut.

Aplikasi herbisida berbahan aktif oksifluorfen dan sulfentrazon menunjukkan hasil pengendalian gulma total yang cenderung lebih baik dibandingkan dengan perlakuan bahan aktif etil pirazosulfuron dan perlakuan kontrol. Hasil tersebut ditunjukkan pada Tabel 6, bahwa pada pengamatan 56 HST herbisida berbahan aktif oksifluorfen dan sulfentrazon masih efektif dalam menekan pertumbuhan gulma dengan kemampuan penghambatan tergolong cukup sampai sedang pada skoring efektivitas herbisida.

Faktor penentu efektivitas herbisida salah satunya yaitu waktu aktif herbisida di dalam tanah atau disebut persistensi. Persistensi herbisida etil pirazosulfuron hanya mencapai 28 sampai 45 hari (Naveen 2009). Persistensi herbisida oksifluorfen dalam tanah dapat bertahan sekitar 2 sampai 3 bulan (Ashton dan Craft 1981), sedangkan persistensi herbisida sulfentrazon dalam tanah dapat mencapai 182 hari setelah aplikasi (Laurenco dan Carvalho 2015) sehingga mampu menekan pertumbuhan gulma pada lahan dengan waktu yang cukup lama.

Hasil pengamatan fitotoksisitas herbisida pada tanaman kacang panjang (Tabel 7) tidak menunjukkan

Tabel 11. Pengaruh herbisida berbahan aktif etil pirazosulfuron, oksifluorfen, dan sulfentrazon terhadap produksi tanaman kacang panjang.

\begin{tabular}{|c|c|c|c|}
\hline Perlakuan & $\begin{array}{l}\text { Jumlah } \\
\text { Polong }\end{array}$ & $\begin{array}{l}\text { Panjang } \\
\text { Polong }(\mathrm{cm})\end{array}$ & $\begin{array}{l}\text { Berat } \\
\text { Segar (kg) }\end{array}$ \\
\hline A (Kontrol) & $162,75 \mathrm{~cd}$ & 56,42 & $3,04 \mathrm{~cd}$ \\
\hline B (Oksifluorfen, peleton) & $148,00 \mathrm{~d}$ & 57,16 & $2,74 \mathrm{~cd}$ \\
\hline C (Etil pirazosulfuron, peleton) & $185,25 \mathrm{bcd}$ & 57,81 & $3,74 \mathrm{~b}$ \\
\hline D (Sulfentrazon, peleton) & $259,00 \mathrm{a}$ & 58,23 & $5,04 \mathrm{a}$ \\
\hline E (Oksifluorfen, kanton tavi) & $158,50 \mathrm{~d}$ & 56,41 & $2,68 \mathrm{~d}$ \\
\hline G (Sulfentrazon, kanton tavi) & $210,25 \mathrm{~b}$ & 56,14 & $3,99 \mathrm{~b}$ \\
\hline
\end{tabular}

Keterangan: Angka-angka pada kolom yang sama diikuti oleh huruf yang sama menunjukkan berbeda tidak nyata pada uji DMRT taraf $5 \%$. 
adanya gejala perubahan fisiologis pada daun dan tinggi tanaman sebagai dampak keracunan herbisida, sehingga dapat disebutkan bahwa herbisida berbahan aktif oksifluorfen, etilpirazosulfuron, dan sulfentrazon tergolong herbisida selektif. Pada pengamatan tinggi tanaman (Tabel 8) dan jumlah daun (Tabel 9) menunjukkan bahwa aplikasi herbisida mampu meningkatkan tinggi tanaman dan jumlah daun melalui penghambatan pertumbuhan gulma dan mengurangi persaingan antara gulma dengan tanaman kacang sehingga pertumbuhan tanaman lebih optimal.

Aplikasi herbisida berbahan aktif etil pirazosulfuron dan sulfentrazon dapat meningkatkan jumlah produksi tanaman kacang panjang varietas peleton dan kanton tavi dibandingkan dengan perlakuan kontrol khususnya peningkatan jumlah polong dan berat segar. Pada aplikasi herbisida berbahan aktif oksifluorfen hasil produksi tanaman kacang panjang cenderung mengalami penurunan jumlah polong dan berat segar polong jika dibandingkan dengan perlakuan kontrol.

Aplikasi herbisida berbahan aktif oksifluorfen, etil pirazosulfuron dan sulfentrazon pada penelitian ini secara nyata efektif dalam mengendalikan gulma teki dan berdaun lebar tetapi tidak nyata dalam mengendalikan gulma rumput. Aplikasi herbisida berbahan aktif oksifluorfen, etil pirazosulfuron, dan sulfentrazon tidak meracuni tanaman kacang panjang varietas peleton dan kanton tavi sehingga tergolong herbisida selektif, tetapi aplikasi herbisida oksifluorfen pada varietas peleton dan kanton tavi dapat menurunkan produksi tanaman kacang panjang.

\section{Pernyataan tidak ada konfik kepentingan}

Semua penulis artikel ini menyatakaan bahwa tidak ada konflik kepentingan terkait penelitian dan hasil penelitian ini.

\section{DAFTAR PUSTAKA}

Ashton FM, Craft AS. 1981. Mode of Action of Herbicides. Wiley Publisher, New Jersey (US).

Christia A, Sembodo DRJ, Hidayat KF. 2016. Pengaruh jenis dan tingkat kerapatan gulma terhadap pertumbuhan dan produksi kedelai (Glycine max L. Merr). Agrotek Tropika 4 (1):22-28. DOI: 10.23960/jat.v4i1.1895.

Direktorat Jenderal Hortikultura Kementerian Pertanian. 2015. Statistik Produksi Hortikultura Tahun 2014. Jakarta: Direktorat Jenderal Hortikultura Kementerian Pertanian.

Guntoro D, Agustina K, Yusrida. 2013. Efikasi herbisida penoksulam pada budidaya padi sawah pasang surut untuk intensifikasi lahan suboptimal. Jurnal Lahan Sub Optimal 2 (2):144-150. DOI: 10.33230/JLSO.2.2.2013.54.

Laurenco RC, Carvalho SJP. 2015. Bioindicator demonstrates high persistence of sulfentrazone in dry soil. Agropec Tropica 45 (3):326-332. DOI: 10.1590/1983-40632015v4535776.

Naveen DV. 2009. Persictence and behaviour of pyrazosulfuronethyl in transplanted rice ecosytem. [Disertasi]. University of Agricultural Science, Bangalore.

Sarido L. 2018. Effek kehadiran gulma terhadap produktifitas tanaman kacang panjang (Vigna sinensis L.). Agrifor 17 (1):123-130

Simanjuntak R, Wicaksono KP, Tyasmoro SY. 2016. Pengujian efikasi herbisida berbahan aktif pirazosulfuron etil $10 \%$ untuk penyiangan pada budidaya padi sawah (Oryza sativa L.). Jurnal Produksi Tanaman 4 (1):31-39. 